\title{
Time and response matching with topographically different responses
}

\author{
JOHN HANSON and LEONARD GREEN \\ Washington University, St. Louis, Missouri
}

\begin{abstract}
Four pigeons were exposed to several nonindependent concurrent variable-interval schedules of reinforcement. One schedule component required a keypecking response; the other component required a treadlepressing response. The birds matched the ratio of their behavior (as measured by responses and time) between the two topographically different responses to the ratio of reinforcement in those two components. When additional foods not contingent on a keypeck or treadlepress were then added, the birds matched time spent in the components to total rates of food delivered in those components; response matching was somewhat disrupted. The matching law, developed under concurrent variable-interval schedules requiring similar responses, can thus account for choice behavior involving topographically different responses.
\end{abstract}

How organisms distribute their behavior among response alternatives is of considerable interest to psychologists, economists, and behavioral biologists. One of the more successful formulations of such choice behavior is the matching law (Herrnstein, 1961, 1970), which states that the ratio of responses, or the ratio of time, to two alternatives matches the ratio of the reinforcements obtained in those alternatives. That is,

$$
B_{1} / B_{2}=r_{1} / r_{2}
$$

where $B_{1}$ and $B_{2}$ are responses to or time on alternatives 1 and 2 , respectively, and $r_{1}$ and $r_{2}$ are the reinforcements obtained from those alternatives.

In his generalization of the matching equation, Baum (1974) noted that the logarithm of the ratio of behavior is a linear function of the logarithm of the ratio of reinforcement obtained:

$$
\log \left(B_{1} / B_{2}\right)=a \log \left(r_{1} / r_{2}\right)+\log b,
$$

where $a$ is the slope of the line and $\log b$ is the $y$ intercept. When a subject matches, both $a$ and $b$ take on values of 1.0, and Equation 2 reduces to Equation 1. Undermatching is represented by a slope less than unity $(a<1)$; the subject overvalues the leaner schedule of reinforcement. Overmatching is represented by a slope greater than unity $(a>1)$; the subject overvalues the richer schedule of reinforcement. Bias, a systematic preference for one of the two alternatives, is represented in deviations of $b$ from a value of one, seen as deviations in the $y$ intercept from zero.

Response and time matching have generally been supported by the results from studies of choice in which a variety of reinforcement schedules have been employed

We gratefully acknowledge the many contributions of the members of the Psychonomy Cabal in the running of these experiments. Requests for reprints should be addressed to Leonard Green, Department of Psychology, Washington University, St. Louis, MO 63130. (see Baum, 1979; de Villiers, 1977; Myers \& Myers, 1977; Weardon \& Burgess, 1982). The matching law has been extended to situations in which qualitatively different reinforcers are delivered from the two alternatives (Hollard \& Davison, 1971; Miller, 1976), although an "economic," or behavioral maximization, interpretation has also been proposed (Elsmore, Fletcher, Conrad, \& Sodetz, 1980; Hursh \& Natelson, 1981; Rachlin, Battalio, Kagel, \& Green, 1981). In almost all of the research on matching, however, the responses required to produce reinforcement have been topographically the same on the alternatives (e.g., pecking one of two keys or pressing one of two levers). The use of topographically different responses for each alternative has received scant attention (Davison \& Ferguson, 1978; McSweeney, 1978; Wheatley \& Engberg, 1978). This relative neglect is somewhat surprising, given the importance attained by the matching law as a general descriptor of choice. Furthermore, in more naturalistic settings than those of the operant laboratory, organisms must often allocate their behavior across alternatives that require rather different responses; for example, both scratching at the ground and pecking may be responses emitted by various avian species in searching for or acquiring food. Thus, in order to further assess the generality of the matching law, we studied pigeons' allocation of behavior under concurrent variable-interval (VI) schedules of reinforcement in which reinforcement from one alternative required a keypeck response while reinforcement from the other alternative required a treadlepress response. In so doing, we compared two measures of behavioral allocation: response distribution and time distribution.

Herrnstein's (1970) matching law predicted well the results of Rachlin and Baum (1972), in whose study a schedule of freely delivered food was superimposed upon a VI schedule for keypecking in pigeons. Although such response-independent food deliveries do affect response rate, their effect on choice and the matching law when 
different responses are required remains unknown. Thus, a second purpose of the present experiments was to evaluate whether the different topographical responses would be differentially affected by the addition of free-food deliveries, and how time and response matching might be so influenced.

\section{EXPERIMENT 1}

\section{Method}

Subjects. Four male White Carneaux pigeons served as subjects. All had prior experience in pecking keys for delayed access to grain. The subjects were maintained at approximately $80 \%$ of their freefeeding body weights; water and grit were always available in their home cages.

Apparatus. The apparatus was a $30.5 \times 30.5 \times 30.5 \mathrm{~cm} \mathrm{Ger}-$ brands operant chamber placed within a sound- and light-attenuating enclosure. White noise was continuously present; a small fan provided ventilation. All progamming and data recording were accomplished with standard electromechanical relay equipment located in an adjoining room.

The chamber was illuminated by a 7-W white houselight located on the ceiling at the rear of the chamber. It was lit throughout the experimental session except during food deliveries. An opening, $5.0 \mathrm{~cm}$ in diameter and centered on the front wall $10.0 \mathrm{~cm}$ above the grid floor, allowed access to the food hopper. When reinforcement was delivered, the hopper was activated and illuminated by two 7-W white bulbs. Reinforcement consisted of 4-sec access to mixed grains

The front wall also contained two response keys and a retractable treadle. The keys, which required a force of $0.25 \mathrm{~N}$ to operate and produce a feedback click, were $1.9 \mathrm{~cm}$ in diameter and $21.0 \mathrm{~cm}$ from the floor. The left and right keys were located $8.0 \mathrm{~cm}$ from the left and right walls, respectively. The left key served as the changeover $(\mathrm{CO})$ key and could be transilluminated with white light. The right key could be transilluminated with red light. Pecking the left $(\mathrm{CO})$ key alternated the right (red) key with the extension of the treadle.

The retractable treadle was located beneath the right response key. The treadle was a $5.0 \times 5.0 \mathrm{~cm}$ stainless steel plate, the center of which was $4.5 \mathrm{~cm}$ above the floor and $7.0 \mathrm{~cm}$ from the side wall. When extended, the treadle projected $5.0 \mathrm{~cm}$ into the chamber, inclined at a $45^{\circ}$ angle. A force of $0.40 \mathrm{~N}$ was required to operate the treadle and produce a feedback click. When retracted, the surface of the treadle was flush with the front wall.

Procedure. All birds were hand shaped to treadlepress during the first session. By the third session all birds were treadlepressing on a VI 60 -sec schedule. During the fourth session the treadle was retracted, the right response key was illuminated, and the birds were allowed to keypeck for food. The birds were placed directly into the first experimental condition in the fifth session.

A series of nonindependent concurrent variable-interval variableinterval (Conc VI VI) schedules of reinforcement were studied. One schedule was associated with the right response key and the other schedule was associated with the treadle. Subjects were studied 7 days a week unless their weights exceeded $20 \mathrm{~g}$ of their $80 \%$ weight. Sessions ended after 50 food reinforcements. Each experimental condition was in effect for 15 sessions. The manipulandum that was available at the beginning of each session, that is, the key or the treadle, alternated daily.

A Findley-concurrent schedule was programmed in which one component required a keypeck response and the other component required a treadlepress response to produce food reinforcement. Responses on the left (CO) key alternated the manipulandum available for responding. When the session began, the houselight and
CO key were illuminated and one manipulandum was active. If the response key was active, it was illuminated red and the treadle remained retracted; if the treadle was active, it was extended into the chamber and the right response key remained dark. Responding on either of the keys or on the treadle was ineffective for $2.5 \mathrm{sec}$ following a changeover response $(2.5 \mathrm{sec}$ was the time required for the treadle to fully extend or retract). During this changeover delay (COD) both the $\mathrm{CO}$ and response keys were dark. In addition, the first response on either manipulandum following a changeover could not produce reinforcement.

Reinforcement was arranged by two nonindependent VI timers according to schedules following the progression of Fleshler and Hoffman (1962). Both timers were stopped during the 2.5-sec changeover delay; otherwise they ran until reinforcement was set up for one of the manipulanda, at which point both were stopped until that reinforcer had been collected (Stubbs \& Pliskoff, 1969). This procedure assured that the obtained relative rates of reinforcement equaled those programmed. Although this procedure may have had the effect of forcing subjects closer to indifference (equal responding on the two manipulanda), its use was considered necessary to ensure continued sampling of both response alternatives when lean schedules of reinforcement were studied and responding resulted in low rates of reinforcement.

Each bird was studied on a different order of eight experimental conditions, expressed in terms of the logarithm of the ratio of reinforcement programmed [i.e., $\left.\log \left(r_{k} / r_{i}\right)\right]$. The initial condition for all subjects was one of equal rates of reinforcement for each component of the concurrent schedule $\left[\log \left(r_{k} / r_{t}\right)=0\right]$; the actual schedule in effect was a Conc VI $60-\mathrm{sec}$ VI 60 -sec. The final condition for each subject was a replication of this initial condition. The intervening conditions were composed of unique orders of the following $\log$ ratios of reinforcement: $0.95,0.60,0.30,-0.30,-0.60$, and -0.95 . The actual schedules used were Conc VI 30-sec VI 270 sec, Conc VI 30-sec VI 120-sec, Conc VI 30-sec VI 60-sec, Conc VI 60-sec VI 30-sec, Conc VI $120-\mathrm{sec}$ VI $30-\mathrm{sec}$, and Conc VI $270-\mathrm{sec}$ VI 30-sec, respectively. The schedule for the key response component is the first of each pair. Each bird was thus studied on a total of eight conditions including the replication (except Bird 12, which was not studied on the $-0.95 \log$-ratio-ofreinforcement condition).

Data recorded were the number of keypeck and treadlepress responses, the number of reinforcements obtained for each, the number of changeover responses, and the time spent in each component (measured from the end of the COD to the next changeover response)

\section{Results}

Table 1 presents the median results from the last 5 days of each condition for each bird. Presented are: the log of the ratio of reinforcement, the local response rates (responses divided by time in each component), the local reinforcement rates (number of reinforcements divided by time in each component), and the number of changeover responses.

The number of changeover responses followed a systematic course for all subjects, with fewer changeovers at the higher and lower ratios of reinforcement and the greatest number of changeovers at the equiprobable reinforcement rates (see also Brownstein \& Pliskoff, 1968; Herrnstein, 1961).

Figure 1 shows both the $\log$ of the ratio of the number of responses in each component and the log of the ratio of time spent in each component as a function of the log of the reinforcement ratios for each bird. The equation 
Table 1

Summary of Results for Each Bird From Experiment 1

\begin{tabular}{|c|c|c|c|c|c|c|}
\hline \multirow[b]{2}{*}{ Bird } & \multirow{2}{*}{$\begin{array}{l}\text { Log Reinforcement } \\
\text { Ratio }\left(\log r_{k} / r_{t}\right)\end{array}$} & \multicolumn{2}{|c|}{$\begin{array}{c}\text { Local Response Rate } \\
\text { (Responses/min) }\end{array}$} & \multicolumn{2}{|c|}{$\begin{array}{c}\text { Local Rate of } \\
\text { Reinforcement } \\
\text { (Reinforcement/min) }\end{array}$} & \multirow{2}{*}{$\begin{array}{c}\text { Number of } \\
\text { Changeover } \\
\text { Responses }\end{array}$} \\
\hline & & $\mathbf{K}$ & $T$ & $\mathbf{K}$ & $T$ & \\
\hline 11 & $\begin{array}{l}-0.95 \\
-0.60 \\
-0.30 \\
0.00 \\
0.00^{*} \\
0.30 \\
0.60 \\
0.95\end{array}$ & $\begin{array}{l}54.3 \\
37.4 \\
65.3 \\
74.0 \\
46.6 \\
76.1 \\
74.6 \\
67.9\end{array}$ & $\begin{array}{l}35.2 \\
39.6 \\
47.1 \\
30.9 \\
20.7 \\
42.1 \\
42.1 \\
49.4\end{array}$ & $\begin{array}{l}1.64 \\
2.38 \\
2.93 \\
1.86 \\
1.35 \\
2.67 \\
2.38 \\
2.30\end{array}$ & $\begin{array}{l}1.89 \\
2.23 \\
2.27 \\
1.52 \\
1.19 \\
2.58 \\
1.98 \\
0.90\end{array}$ & $\begin{array}{r}66 \\
96 \\
114 \\
195 \\
158 \\
108 \\
101 \\
65\end{array}$ \\
\hline 12 & $\begin{array}{l}-0.95 \\
-0.60 \\
-0.30 \\
0.00 \\
0.00^{*} \\
0.30 \\
0.60 \\
0.90 \dagger\end{array}$ & $\begin{array}{l}40.4 \\
28.6 \\
46.9 \\
75.2 \\
60.4 \\
33.3 \\
48.0\end{array}$ & $\begin{array}{l}45.4 \\
45.4 \\
29.1 \\
14.2 \\
60.4 \\
25.7 \\
23.2\end{array}$ & $\begin{array}{l}2.04 \\
1.42 \\
1.62 \\
1.00 \\
1.35 \\
1.75 \\
1.73\end{array}$ & $\begin{array}{l}1.88 \\
1.72 \\
2.00 \\
1.49 \\
2.03 \\
1.52 \\
2.47\end{array}$ & $\begin{array}{r}37 \\
43 \\
102 \\
118 \\
162 \\
54 \\
35\end{array}$ \\
\hline 13 & $\begin{array}{l}-0.95 \\
-0.60 \\
-0.30 \\
0.00 \\
0.00^{*} \\
0.30 \\
0.60 \\
0.95\end{array}$ & $\begin{array}{l}39.7 \\
59.2 \\
46.9 \\
46.3 \\
66.3 \\
46.8 \\
41.8 \\
50.3\end{array}$ & $\begin{array}{l}49.5 \\
40.7 \\
57.5 \\
23.8 \\
35.5 \\
42.7 \\
35.8 \\
87.9\end{array}$ & $\begin{array}{l}1.30 \\
2.08 \\
1.70 \\
1.20 \\
1.45 \\
2.09 \\
1.74 \\
2.11\end{array}$ & $\begin{array}{l}2.05 \\
2.25 \\
2.97 \\
1.92 \\
2.25 \\
2.64 \\
3.26 \\
2.60\end{array}$ & $\begin{array}{r}118 \\
149 \\
136 \\
136 \\
231 \\
108 \\
92 \\
62\end{array}$ \\
\hline 14 & $\begin{array}{l}-0.95 \\
-0.60 \\
-0.30 \\
0.00 \\
0.00^{*} \\
0.30 \\
0.60 \\
0.95\end{array}$ & $\begin{array}{l}57.7 \\
50.6 \\
56.7 \\
35.6 \\
53.9 \\
54.1 \\
37.9 \\
41.8\end{array}$ & $\begin{array}{l}36.7 \\
40.7 \\
38.3 \\
19.9 \\
26.7 \\
32.1 \\
38.4 \\
37.0\end{array}$ & $\begin{array}{l}1.67 \\
2.24 \\
2.14 \\
1.31 \\
1.52 \\
1.97 \\
1.97 \\
1.93\end{array}$ & $\begin{array}{l}2.01 \\
2.02 \\
2.58 \\
1.72 \\
1.43 \\
2.26 \\
2.27 \\
1.37\end{array}$ & $\begin{array}{r}53 \\
97 \\
123 \\
179 \\
132 \\
104 \\
89 \\
68\end{array}$ \\
\hline
\end{tabular}

Note-Data presented are the medians of the last 5 days of each condition. $K$ refers to the keypeck component; $T$ refers to the treadlepress component. *Replication. †Not studied.

in each panel describes the best-fitting line (solid line in each panel); the broken lines define matching (i.e., Equation 1). The amount of data variance accounted for by the best-fitting line $\left(r^{2}\right)$ is also given. Regardless of the behavioral measure (responses or time), subjects allocated behavior to each component in proportion to the reinforcement obtained there, as predicted by the matching law. From Equation 2, we would expect the slope of the line describing this relation to equal 1.0, although slopes in the range of 0.90 to 1.11 may be regarded as indicative of matching (Baum, 1979). With the response measure, 2 subjects' data fell within that range. Of the remaining 2 subjects, one slope indicated undermatching (Bird 14; $a=0.867$ ), whereas the other indicated overmatching (Bird $12 ; a=1.34$ ). All subjects' data fell within the range of slopes indicative of matching using the time measure.

The $y$ intercept term of Equation 2 indicates bias for one alternative or the other. The equations for the bestfitting line in each panel in Figure 1 show that all subjects exhibited a positive $y$ intercept (with the exception of Bird 11's time measure), indicating a bias for the keypeck component. Furthermore, this bias term was larger for every pigeon under the response measure than under the time measure.

Averaging across subjects yields values (mean \pm standard deviation) of $a=1.02 \pm 0.19, \log b=0.210 \pm$ 0.06 , and $r^{2}=0.895 \pm 0.04$ for the response measure, and $a=0.980 \pm 0.01, \log b=0.063 \pm 0.08$, and $r^{2}$ $=0.981 \pm 0.01$ for the time measure. The amount of data variance accounted for was greater under the time measure than under the response measure for every pigeon.

Figure 2 presents the log of the ratio of local response rates as a function of the $\log$ of the ratio of reinforcements. The nearly flat slope $(0.012)$ and the $r^{2}$ value (.001) indicate that local response rates remained constant as the reinforcement ratios were varied, with a bias $(y$ intercept $=$ 0.137 ) for the keypeck response, that is, faster responding on the key than on the treadle.

\section{Discussion}

Even though the responses required in the two components were topographically quite dissimilar, subjects matched their responding and amount of time spent in a component to rates of reinforcement obtained in those 


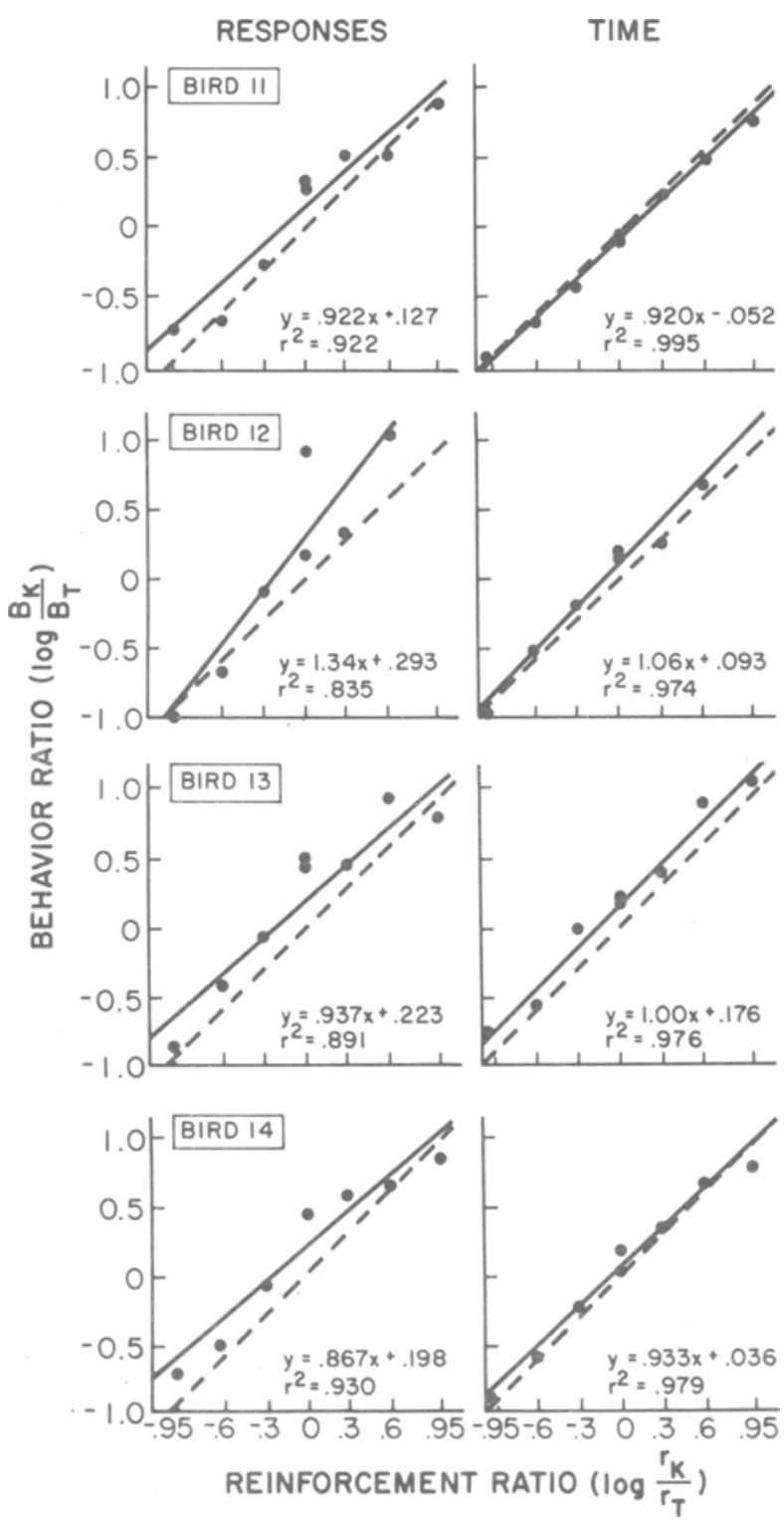

Figure 1. The log of the ratio of responses in each component (left panels) and the $\log$ of the ratio of time spent in each component (right panels) as a function of the $\log$ of the ratio of reinforcements obtained in each component for each bird in Experiment 1. The broken line defines matching; the equation in each panel describes the bestfitting line (solid line). $\mathrm{K}$ refers to keypeck; $\mathrm{T}$ refers to treadlepress.

components. The time measure accounted for more of the data variance than did the response measure for every pigeon.

Previous studies using a keypeck-treadlepress procedure have typically found undermatching. Davison and Ferguson (1978) reported slopes (mean values of $a$ ) of 0.874 and 0.872 for responses and time, respectively. Wheatley and Engberg (1978) reported slopes of 0.697 and 0.627 for responses and time, respectively. McSweeney (1978), in an examination of the effect of changes in the length of the COD on behavioral allocation using the keypeck-treadlepress procedure, also reported undermatching. The mean value of $a$ was 0.70 averged across all values of the COD. The mean value of $a$ under each COD was $0.55,0.75$, and 0.78 for CODs of 0,5 , and $20 \mathrm{sec}$, respectively.

Undermatching is thought to be produced by brief COD requirements or poor discrimination between the two components (Baum, 1974). Wheatley and Engberg (1978) attributed their finding of undermatching in part to the use of a relatively brief (1-sec) COD; Davison and Ferguson (1978), using a slightly longer (2-sec) COD, did find less extreme undermatching. However, McSweeney (1978) found more extreme undermatching than did Davison and Ferguson, even at COD values 10 times longer than those used by Davison and Ferguson. It may be that our use of a $2.5-\mathrm{sec} \mathrm{COD}$, in combination with the restriction that the first response following a changeover could not produce reinforcement, may have contributed to the observation of closer agreement with the predictions of the matching law.

Using topographically different responses would seem to maximize discriminability between the two alternatives, and the use of a Findley-concurrent procedure would also seem to make the active component more discriminable. None of the three previously discussed keypecktreadlepress studies utilized a Findley-concurrent procedure. In addition, our use of a retractable treadle, which clearly indicated which manipulandum and which schedule of reinforcement was in effect, also likely contributed to the present finding of matching.

\section{EXPERIMENT 2}

The matching law predicts that responding is a function of the schedule of reinforcement for that response iteself, and that it is inversely related to the amount of reinforcement from all other sources. The effect on responding of reinforcement from other sources is the same whether those other reinforcers are contingent on some response,

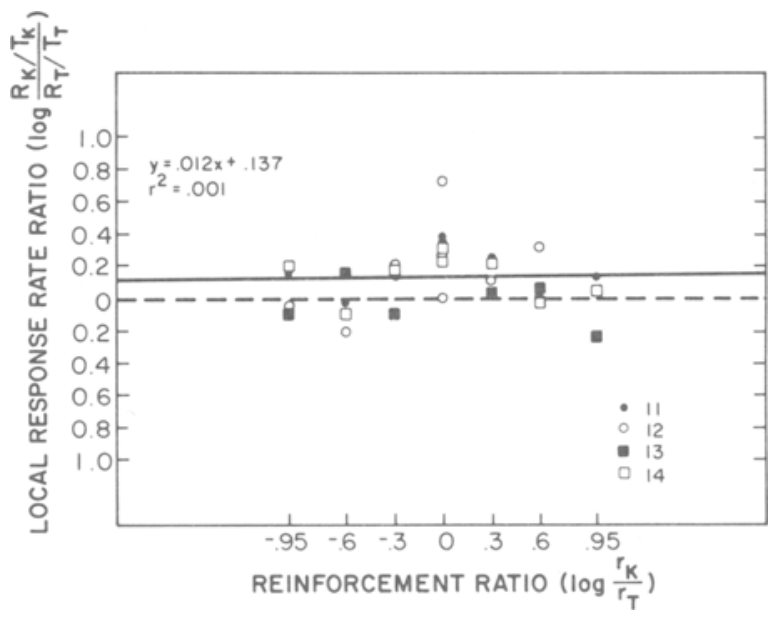

Figure 2. The $\log$ of the ratio of local response rates as a function of the log of the ratio of reinforcements in Experiment 1 . The equation shown describes the best-fitting line (solid line). 
independent of any specified response, or even dependent on a brief period of nonresponding (differential reinforcement of other behavior, or DRO) (Rachlin \& Baum, 1972). It remains to be shown, however, whether, under a concurrent procedure, free-food deliveries have equivalent effects on topographically different responses. The results of Rachlin and Baum suggest that when responseindependent food deliveries, or food delivered after a brief period of nonresponding, are added to the components of a concurrent schedule as employed in our Experiment 1 , the pigeons would redistribute their behavior so as to match responding to the new rates of food delivery. If, however, the topographically different responses are differentially affected by the delivery of these additional foods, then response matching ought to be disrupted. In Experiment 2, therefore, a schedule of food not contingent on the keypeck or treadlepress response was superimposed upon the Conc VI VI schedule of reinforcement, and its influence on the pigeons' time and response distributions was noted.

\section{Method}

Subjects and Apparatus. The subjects and apparatus were the same as those used in Experiment 1.

Procedure. The procedure was basically the same as that of Experiment 1 , with a few modifications. As before, the birds were studied under a Findley-concurrent procedure with nonindependent Conc VI VI schedules. Keypecking and treadlepressing were still the required responses. The duration of food reinforcement was reduced to $3 \mathrm{sec}$ for Experiment 2, so that subjects would be less likely to exceed $20 \mathrm{~g}$ of their $80 \%$ body weight.

In addition to the $\mathbf{5 0}$ response-contingent reinforcements, additional food deliveries were arranged during various experimental conditions. All subjects were studied on five conditions of freefood delivery under each of two complementary concurrent schedules of response-contingent reinforcement (Conc VI 30-sec VI 60sec and Conc VI 60-sec VI 30-sec). The five conditions under each schedule involved varying the number of free-food deliveries in order to alter the ratio of overall food delivery. Each bird was studied under a unique order of the 10 possible conditions. All subjects were first studied on the Conc VI $30-\mathrm{sec}$ VI $60-\mathrm{sec}$ schedule conditions followed by the Conc VI 60 -sec VI $30-\mathrm{sec}$ schedule conditions. Bird 12 was studied on three of the five conditions under each schedule. The actual numbers of free-food deliveries added to each of the components in each condition are given in Table 2.

Delivery of the free foods in each component was scheduled on a variable-time (VT) schedule. The time spent in each component on the previous day was noted and the appropriate VT schedule was then calculated to deliver the correct number and rate of freefood deliveries. For example, if a subject spent a total of $17 \mathrm{~min}$ in a component on the previous day, and 17 free-food deliveries were to be scheduled in that component, then a VT 60 -sec schedule would be programmed. If the subject had spent, say, $34 \mathrm{~min}$ in the component on the previous day, then these 17 food deliveries would now be made on a VT 120-sec schedule. Time spent in each component was monitored daily and any changes in the VT schedule necessary to compensate for redistribution of behavior were made. Notice, however, that the subject need never alter its distribution of time in the components to receive all of the free-food deliveries. Two additional VI timers controlled these free-food deliveries, one operating only when the bird was in the keypeck component and the other operating only when the bird was in the treadlepress component. Therefore, free-food deliveries were scheduled and col- lected only while the subject was in the appropriate component. In addition, the delivery of free food within a component was not completely independent of the bird's responding in that component. So that the free food could be discriminated from the responsecontingent food, the scheduled free food was delivered automatically, provided the pigeon had not responded for $1.67 \mathrm{sec}$. If there had been a keypeck or treadlepress within $1.67 \mathrm{sec}$, then the food was withheld until $1.67 \mathrm{sec}$ had passed without a response, at which time the food was delivered. (Technically, this is a tandem VT DRO $1.67 \mathrm{sec}$ schedule. For ease of discussion, we will continue to describe these additional food deliveries as "free" to distinguish them from the purely response-contingent reinforcers.)

\section{Results and Discussion}

Table 2 presents the median results of the last 5 days under each condition of Experiment 2 for each bird: the $\log$ ratio of total food deliveries (contingent + free), the number of free-food deliveries in each component in each condition, the local response rates, the local food rates (contingent + free), and the number of changeover responses. Unlike the results of Experiment 1, the number of changeover responses followed no systematic course in Experiment 2.

Figure 3 plots the log of both the ratio of the number of responses in each component and the ratio of time spent in a component as a function of the $\log$ of the ratio of total food deliveries for each bird under both concurrent schedule conditions. For each bird the closed circles represent the Conc VI 30 -sec VI 60-sec conditions and the open circles the Conc VI 60-sec VI 30-sec conditions. The equation presented in each panel describes the bestfitting line (solid line) through all of the points; the broken line defines matching (i.e., Equation 1). Also reported is the amount of data variance accounted for by the bestfitting line $\left(r^{2}\right)$.

If the subjects had matched the ratio of responding in the two components to the ratio of response-contingent reinforcement, then all points would fall at $(0.30,0.30)$ for the Conc VI 30-sec VI 60-sec conditions and at $(-0.30,-0.30)$ for the Conc VI 60-sec VI 30-sec conditions. Clearly, as shown in Figure 3, this was not the case.

As in Experiment 1, subjects were closer to matching time spent in a component than to matching responses in a component, with regard to total food obtained (contingent + free) in a component. For every subject, slopes are considerably closer to 1.0 (except for Bird 14), biases for the keypeck component are smaller, and the values of $r^{2}$ are much larger under the time measure.

The addition of free-food deliveries did not have much of an effect on time matching. A comparison of performance between Experiments 1 and 2 using the time measure shows that the slope, the bias term, and the amount of data variance accounted for were not much changed. This was true both within individuals and on average. A comparison using the response measure shows that there was a disruptive effect of the matching relation with the addition of free-food deliveries. The average value of $a$ dropped from 1.02 in Experiment 1 to 0.64 in Experi- 
Table 2

Summary of Results for Each Bird From Experiment 2

\begin{tabular}{|c|c|c|c|c|c|c|c|c|}
\hline \multirow[b]{2}{*}{ Bird } & \multirow{2}{*}{$\begin{array}{c}\log \\
\text { Food Ratio }\end{array}$} & \multicolumn{2}{|c|}{$\begin{array}{l}\text { Number of Free } \\
\text { Food Deliveries }\end{array}$} & \multicolumn{2}{|c|}{$\begin{array}{l}\text { Local Response Rate } \\
\text { (Responses/min) }\end{array}$} & \multicolumn{2}{|c|}{$\begin{array}{c}\text { Local Rate of } \\
\text { Food Delivery } \\
\text { (Deliveries/min) }\end{array}$} & \multirow{2}{*}{$\begin{array}{c}\text { Number of } \\
\text { Changeover } \\
\text { Responses }\end{array}$} \\
\hline & & $\mathbf{K}$ & $\mathbf{T}$ & $\mathbf{K}$ & $\mathrm{T}$ & $\mathbf{K}$ & $T$ & \\
\hline \multicolumn{9}{|c|}{ Conc VI 30-sec VI 60-sec } \\
\hline 11 & $\begin{array}{r}-0.31 \\
0.00 \\
0.00 \\
0.47 \\
0.60\end{array}$ & $\begin{array}{r}0 \\
17 \\
0 \\
17 \\
35\end{array}$ & $\begin{array}{r}50 \\
33 \\
16 \\
0 \\
0\end{array}$ & $\begin{array}{l}60.9 \\
33.9 \\
44.9 \\
37.3 \\
20.3\end{array}$ & $\begin{array}{l}41.5 \\
33.0 \\
44.5 \\
36.6 \\
31.8\end{array}$ & $\begin{array}{l}4.30 \\
3.54 \\
2.73 \\
3.10 \\
3.57\end{array}$ & $\begin{array}{l}5.45 \\
4.10 \\
3.64 \\
1.80 \\
2.73\end{array}$ & $\begin{array}{r}111 \\
97 \\
73 \\
125 \\
73\end{array}$ \\
\hline 12 & $\begin{array}{r}-0.31 \\
0.00 \\
0.60\end{array}$ & $\begin{array}{r}0 \\
17 \\
35\end{array}$ & $\begin{array}{r}50 \\
33 \\
0\end{array}$ & $\begin{array}{l}32.6 \\
21.4 \\
35.3\end{array}$ & $\begin{array}{l}12.4 \\
44.0 \\
36.8\end{array}$ & $\begin{array}{l}3.20 \\
3.11 \\
2.92\end{array}$ & $\begin{array}{l}3.53 \\
3.53 \\
2.72\end{array}$ & $\begin{array}{l}69 \\
50 \\
45\end{array}$ \\
\hline 13 & $\begin{array}{r}-0.31 \\
0.00 \\
0.00 \\
0.47 \\
0.60\end{array}$ & $\begin{array}{r}0 \\
17 \\
0 \\
17 \\
35\end{array}$ & $\begin{array}{r}50 \\
33 \\
16 \\
0 \\
0\end{array}$ & $\begin{array}{l}56.9 \\
31.3 \\
40.4 \\
38.9 \\
40.2\end{array}$ & $\begin{array}{l}32.6 \\
23.2 \\
32.7 \\
35.9 \\
28.2\end{array}$ & $\begin{array}{l}3.62 \\
2.87 \\
2.14 \\
2.61 \\
2.68\end{array}$ & $\begin{array}{l}5.18 \\
3.75 \\
2.64 \\
3.17 \\
3.45\end{array}$ & $\begin{array}{l}152 \\
152 \\
158 \\
122 \\
119\end{array}$ \\
\hline 14 & $\begin{array}{r}-0.31 \\
0.00 \\
0.00 \\
0.47 \\
0.60\end{array}$ & $\begin{array}{r}0 \\
17 \\
0 \\
17 \\
35\end{array}$ & $\begin{array}{r}50 \\
33 \\
16 \\
0 \\
0\end{array}$ & $\begin{array}{l}25.8 \\
27.8 \\
46.7 \\
33.1 \\
27.8\end{array}$ & $\begin{array}{l}19.1 \\
24.4 \\
28.7 \\
35.1 \\
16.5\end{array}$ & $\begin{array}{l}3.56 \\
3.09 \\
2.87 \\
3.35 \\
3.13\end{array}$ & $\begin{array}{l}3.30 \\
4.23 \\
3.55 \\
2.44 \\
2.95\end{array}$ & $\begin{array}{r}109 \\
91 \\
109 \\
94 \\
74\end{array}$ \\
\hline \multicolumn{9}{|c|}{ Conc VI 60-sec VI 30-sec } \\
\hline 11 & $\begin{array}{r}-0.60 \\
-0.47 \\
0.00 \\
0.00 \\
0.31\end{array}$ & $\begin{array}{r}0 \\
0 \\
33 \\
16 \\
50\end{array}$ & $\begin{array}{r}35 \\
17 \\
17 \\
0 \\
0\end{array}$ & $\begin{array}{r}53.9 \\
102.0 \\
22.7 \\
50.4 \\
18.5\end{array}$ & $\begin{array}{l}20.6 \\
39.7 \\
23.4 \\
25.6 \\
16.2\end{array}$ & $\begin{array}{l}3.70 \\
2.03 \\
3.94 \\
2.98 \\
3.15\end{array}$ & $\begin{array}{l}3.74 \\
3.21 \\
4.39 \\
3.29 \\
3.19\end{array}$ & $\begin{array}{r}107 \\
88 \\
92 \\
107 \\
89\end{array}$ \\
\hline 12 & $\begin{array}{r}-0.47 \\
0.00 \\
0.31\end{array}$ & $\begin{array}{r}0 \\
33 \\
50\end{array}$ & $\begin{array}{r}17 \\
17 \\
0\end{array}$ & $\begin{array}{l}67.0 \\
25.9 \\
16.6\end{array}$ & $\begin{array}{l}34.9 \\
20.0 \\
15.6\end{array}$ & $\begin{array}{l}3.18 \\
2.72 \\
1.53\end{array}$ & $\begin{array}{l}2.56 \\
2.88 \\
2.75\end{array}$ & $\begin{array}{l}50 \\
54 \\
66\end{array}$ \\
\hline 13 & $\begin{array}{r}-0.60 \\
-0.47 \\
0.00 \\
0.00 \\
0.31\end{array}$ & $\begin{array}{r}0 \\
0 \\
33 \\
16 \\
50\end{array}$ & $\begin{array}{r}35 \\
17 \\
17 \\
0 \\
0\end{array}$ & $\begin{array}{l}41.7 \\
27.4 \\
36.5 \\
39.7 \\
30.3\end{array}$ & $\begin{array}{r}17.4 \\
6.6 \\
21.2 \\
25.3 \\
15.5\end{array}$ & $\begin{array}{l}2.47 \\
1.01 \\
2.48 \\
1.35 \\
2.42\end{array}$ & $\begin{array}{l}3.02 \\
1.61 \\
4.11 \\
3.48 \\
3.30\end{array}$ & $\begin{array}{l}188 \\
231 \\
118 \\
144 \\
126\end{array}$ \\
\hline 14 & $\begin{array}{r}-0.60 \\
-0.47 \\
0.00 \\
0.00 \\
0.31\end{array}$ & $\begin{array}{r}0 \\
0 \\
33 \\
16 \\
50\end{array}$ & $\begin{array}{r}35 \\
17 \\
17 \\
0 \\
0\end{array}$ & $\begin{array}{l}50.7 \\
42.4 \\
37.0 \\
34.7 \\
35.1\end{array}$ & $\begin{array}{l}23.8 \\
27.7 \\
22.5 \\
13.4 \\
15.2\end{array}$ & $\begin{array}{l}3.20 \\
2.80 \\
3.76 \\
2.34 \\
3.40\end{array}$ & $\begin{array}{l}3.70 \\
3.45 \\
3.97 \\
2.58 \\
3.55\end{array}$ & $\begin{array}{r}71 \\
123 \\
82 \\
109 \\
103\end{array}$ \\
\hline
\end{tabular}

Note-Data presented are the medians of the last 5 days of each condition. $K$ refers to the keypeck component; $T$ refers to the treadlepress component.

ment 2 ; similarly, $r^{2}$ dropped from 0.895 to 0.667 . Although Bird 11 was most noticeably affected by the addition of free-food deliveries, the remaining 3 subjects did show some disruption: the amount of variance accounted for by the best-fitting lines $\left(r^{2}\right)$, using the response measure, was considerably less for each pigeon in Experiment 2 than in Experiment 1. The values of $a$ found in Experiment 2 are comparable to those observed in previous keypeck-treadlepress experiments (Davison \& Ferguson, 1978; McSweeney, 1978; Wheatley \& Engberg, 1978).

Local response rates on both manipulanda were typically lower in Experiment 2 than in Experiment 1 (compare Tables 1 and 2). Again, response rates were lower on the treadle than on the key, and both response rates were relatively stable across conditions; that is, there was no consistent trend to changes in response rate. The lower response rate observed in Experiment 2 is, of course, due to the addition of the free-food deliveries and/or an effect of the DRO contingency, which required pauses in responding for subjects to receive these additional food deliveries.

\section{GENERAL DISCUSSION}

How animals apportion their behavior among alternatives depends on the consequences of that apportionment. There are several variables that modify the apportionment of behavior, including the nature of the responses required, the type of reinforcers delivered, and the sched- 


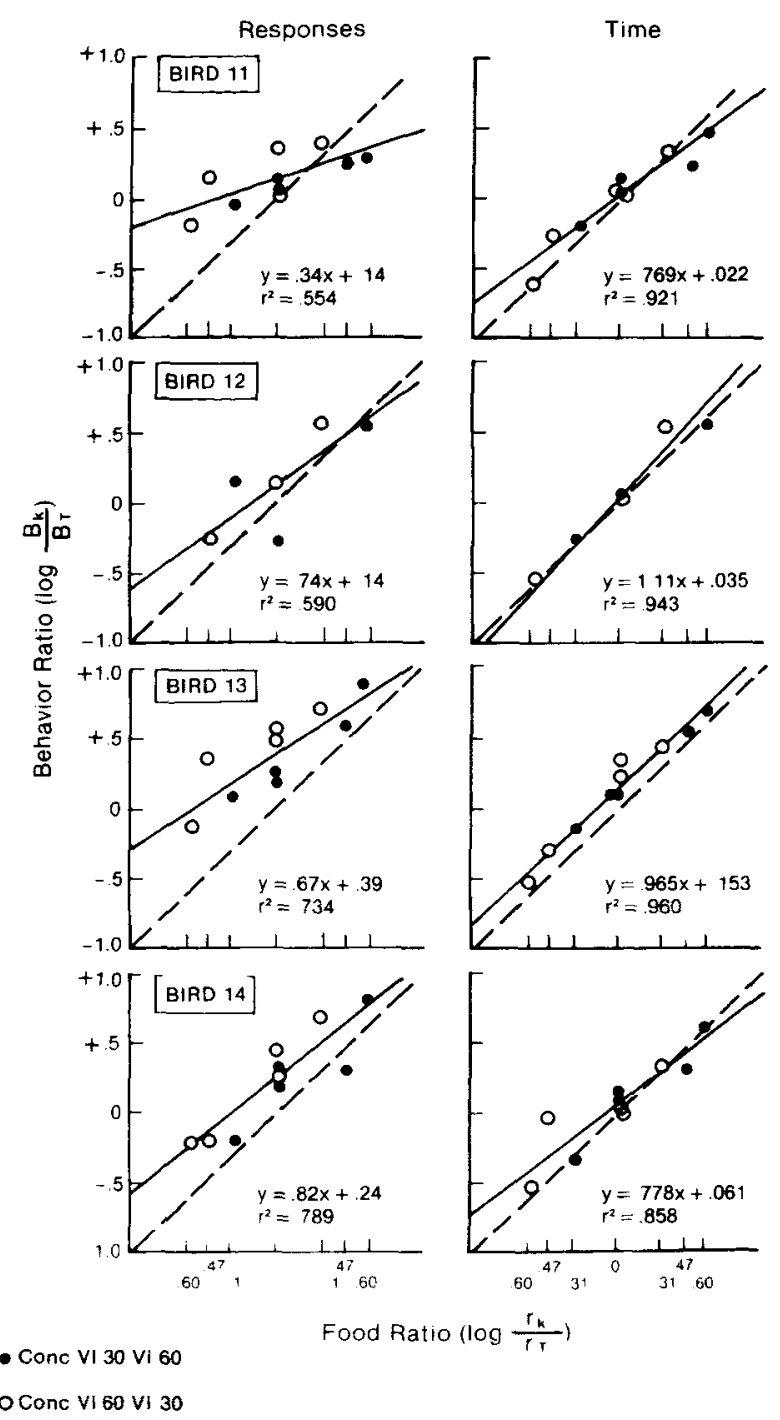

Figure 3. The log of the ratio of responses in each component (left panels) and the $\log$ of the ratio of time spent in each component (right panels) as a function of the log of the ratio of foods obtained in each component for each bird in Experiment 2. The broken line defines matching; the solid line is the best-fitting line described by the equation in each panel. $K$ refers to keypeck; $T$ refers to treadlepress. Open circles represent data from the Cone VI 60-sec VI 30-sec conditions; closed circles represent data from the Conc VI 30-sec VI 60sec conditions.

ule constraints controlling the delivery of those reinforcers.

In order to assess the differential effects of these variables, a standard reference point or a theoretical prediction of how behavior should be distributed is needed. This is provided by the matching law as applied to the standard two-key Conc VI VI operant situation. In this setting variations are minimized: the responses required in each component, the reinforcers delivered in each component, and the nature of the schedules operative in each component are all identical. Only the exact values of the schedules are permitted to vary.
In Experiment 1, the matching law predicted well the distribution of behavior across different ratios of reinforcement even when the responses required were topographically dissimilar. The present results were in closer agreement with the predictions of the matching law than were the results of previous experiments (Davison \& Ferguson, 1978; McSweeney, 1978; Wheatley \& Engberg, 1978); that is, slopes were closer to one. This is likely due to procedural differences: we used a Findleyconcurrent procedure and a retractable treadle, which may have made the active component more discriminable. Although the imposition of free food (Experiment 2) resulted in some disruption of the response-matching relationship, subjects continued to match time in a component to total numbers of food deliveries in a component.

The bias term of the generalized matching law reflects "the magnitude of preference when apparent equality of reinforcement...would predict indifference" (Baum, 1974 , p. 233). Bias may occur for several reasons, including the use of qualitatively different schedules or reinforcers, a discrepancy between programmed and obtained rates of reinforcement, or response bias. In the present experiments, the schedules in both components were variable-interval; similarly, all reinforcement consisted of access to mixed grain. The use of the Stubbs and Pliskoff (1969) procedure equated programmed and obtained rates of reinforcement. The bias observed, then, seems to be explicable in terms of response bias. As did Wheatley and Engberg (1978) and Davison and Ferguson (1978), but unlike McSweeney (1978), we observed a bias in favor of the keypeck response. This bias was greater when responding was the measure of behavior than when time spent in a component was the measure. The force required to activate the treadle was greater than that required to activate the response key, which might account for some of the response bias.

These results further enhance the generality of the matching law's ability to relate simple changes in the distribution of behavior to changes in the outcomes from those behaviors. Regardless of the topographical differences between the required responses, the matching law accounted well for the distribution of behavior between components. Furthermore, time was a consistently more reliable measure of the distribution of behavior than was response (i.e., time conformed more closely to the matching equation). This provides additional support for the view that all behavior can be measured on a common scale of time (see Baum \& Rachlin, 1969).

\section{REFERENCES}

BaUM, W. M. (1974). On two types of deviation from the matching law: Bias and undermatching. Journal of the Experimental Analysis of Behavior, 22, 231-242.

BAUM, W. M. (1979). Matching, undermatching, and overmatching in studies of choice. Journal of the Experimental Analysis of Behavior, 32, 269-281.

Baum, W. M., \& RaChlin, H. C. (1969). Choice as time allocation. Journal of the Experimental Analvsis of Behavior, 12, 861-874. Brownstein, A. J., \& Pliskoff, S. S (1968). Some effects of relative 
reinforcement rate and changeover delay in response-independent concurrent schedules of reinforcement. Journal of the Experimental Analysis of Behavior, 11, 683-688.

Davison, M., \& Ferguson, D. (1978). The effects of different component response requirements in multiple and concurrent schedules. Journal of the Experimental Analysis of Behavior, 29, 283-295.

DE VILliers, P. (1977). Choice in concurrent schedules and a quantitative formulation of the law of effect. In W. K. Honig \& J. E. R. Staddon (Eds.), Handbook of operant behavior. Englewood Cliffs, NJ: Prentice-Hall.

Elsmore, T. F., Fletcher, G. V., Conrad, D. G., \& Sodetz, F. J. (1980). Reduction of heroin intake in baboons by an economic constraint. Pharmacology, Biochemistry \& Behavior, 13, 729-731.

Fleshler, M., \& HofFMAN, H. S. (1962). A progression for generating variable interval schedules. Journal of the Experimental Analysis of Behavior, 5, 529-530.

HerRnstein, R. J. (1961). Relative and absolute strength of response as a function of frequency of reinforcement. Journal of the Experimental Analysis of Behavior, 4, 267-272.

Herrnstein, R. J. (1970). On the law of effect. Journal of the Experimental Analysis of Behavior, 13, 242-266.

Hollard, V., \& Davison, M. C. (1971). Preference for qualitatively different reinforcers. Journal of the Experimental Analysis of Behavior, 16, 375-380.

HURSH, S. R., \& NATELSON, B. H. (1981). Electrical brain stimulation and food reinforcement dissociated by demand elasticity. Physiology \& Behavior, 26, 509-515.

MCSWEENEY, F. K. (1978). Prediction of concurrent keypeck treadle- press responding from simple schedule performance. Animal Learning \& Behavior, 6, 444-450.

Miller, H. L. (1976). Matching-based hedonic scaling in the pigeon. Journal of the Experimental Analysis of Behavior, 26, 335-347.

MYERS, D. L., \& MYERS, L. E. (1977). Undermatching: A reappraisal of performance on concurrent variable-interval schedules of reinforcement. Journal of the Experimental Analysis of Behavior, 25, 203-214.

Rachlin, H., Battalio, R., Kagel, J., \& Green, L. (1981). Maximization theory in behavioral psychology. The Behavioral \& Brain Sciences, 4, 371-388.

Rachlin, H., \& BAUM, W. M. (1972). Effects of alternative reinforcement: Does the source matter? Journal of the Experimental Analysis of Behavior, 18, 231-241.

Stuess, D. A., \& Pliskoff, S. S. (1969). Concurrent responding with fixed relative rate of reinforcement. Journal of the Experimental Analysis of Behavior, 12, 887-897.

WEARDON, J. H., \& BuRgESs, I. S. (1982). Matching since Baum (1979). Journal of the Experimental Analysis of Behavior, 38, 339-348.

WheAtley, K. L., \& EngBerg, L. A. (1978). Choice performance in several concurrent key-peck treadle-press reinforcement schedules. Journal of the Experimental Analysis of Behavior, 29, 181-190.

(Manuscript received March 31, 1986; revision accepted for publication June 10,1986 ). 